\title{
HEARING TESTER - MOBILE APPLICATION FOR HEARING LOSS SCREENING
}

\author{
Krzysztof KRZYŻEK****, Maciej KŁACZYŃSKI** \\ * GE Healthcare IT CoE, AVIA Building, Zyczkowskiego 20 \\ 31-864 Krakow, Poland, email: krzyzek.krzysztof@ gmail.com \\ ** AGH University of Science and Technology, Faculty of Mechanical Engineering and Robotics \\ Adama Mickiewicza 30, 30-059 Kraków, Poland, e-mail: maciej.klaczynski@agh.edu.pl
}

Abstract

The article presents results of the work on creation of an application for Android mobile devices to perform hearing screening using pure-tone air conduction audiometry. The application was created in accordance with the procedure defined in the ISO 8253-1: 2010 standard and is to serve the widest possible group of people in a domestic environment, using headphones included with mobile devices. The effectiveness of the application was verified by performing comparative hearing tests on a representative group of patients with different hearing status. Validation was performed using the Interacoustics AD629 clinical audiometer and procedures adopted in the standards. The results of the test comparison were satisfactory. The mean error of the hearing threshold tested using the mobile application, compared to the clinical audiometer was $5.2 \mathrm{dBHL}$. In addition, the hearing threshold curves for the mobile application are similar in shape to the hearing thresholds for the clinical audiometer and coincide with the auditory experiences of the patients.

Keywords: hearing screening, hearing test, hearing loss, hearing impairment, vibroacoustic diagnostics

\section{TESTER SŁUCHU - MOBILNA APLIKACJA DO PRZESIEWOWYCH BADAŃ UTRATY SŁUCHU}

\section{Streszczenie}

Artykuł przedstawia wyniki prac nad stworzeniem aplikacji na urządzenia mobilne z systemem Android w celu wykonania przesiewowych badań słuchu w zakresie progowej audiometrii tonalnej przy przewodnictwie powietrznym. Aplikacja została stworzona zgodnie z procedurą określoną w normie ISO 8253-1:2010 i ma służyć jak najszerszej grupie osób w domowych warunkach badań przy wykorzystaniu słuchawek dedykowanych urządzeniom mobilnym. Działanie aplikacji zostało zweryfikowane poprzez wykonanie porównawczych badań słuchu na reprezentatywnej grupie pacjentów o zróżnicowanym stanie słuchu. Walidację przeprowadzono przy użyciu audiometru klinicznego Interacoustics AD629 i procedur przyjętych w normach. Wyniki badań porównawczych okazały się zadowalające. Średni błąd zbadanego progu słyszenia przy pomocy aplikacji mobilnej, w porównaniu do badań przeprowadzonych przy pomocy audiometru klinicznego, wyniósł $5.2 \mathrm{dBHL}$. Dodatkowo, krzywe progu słyszenia dla aplikacji mobilnej są zbliżone w kształcie do krzywych progu słyszenia dla audiometru klinicznego i pokrywają się z wrażeniami słuchowymi pacjentów.

Słowa kluczowe: badania przesiewowe słuchu, utrata słuchu, upośledzenie słuchu, diagnostyka wibroakustyczna

\section{INTRODUCTION}

Nowadays, more and more people are hearingimpaired. Noise has become an indispensable element of every human life - on the streets, in shops, at work or even in the comfort of our homes. People are constantly exposed to excessive and negative noise, i.e. undesirable sounds in an analyzed place and a given person [3].

The Directive 2003/10/EC of the European Parliament and the Council of 6 February 2003 [1], on the minimum health and safety requirements regarding the exposure of workers to the risks arising from physical agents (noise), constitutes the current European legislation regulating the protection of workers from the risk of noiseinduced hearing loss. According to this Directive the exposure limit values and exposure action values in respect to the daily noise exposure levels and peak sound pressure are fixed at:

a) exposure limit values:

$\mathrm{L}_{\mathrm{Ex}, 8 \mathrm{~h}}=87 \mathrm{~dB}(\mathrm{~A})$ and $\mathrm{P}_{\text {peak }}=200 \mathrm{~Pa}(140 \mathrm{~dB}(\mathrm{C}) \mathrm{re}$. $20 \mu \mathrm{Pa}$ ),

b) upper exposure action values:

$\mathrm{L}_{\mathrm{Ex}, 8 \mathrm{~h}}=85 \mathrm{~dB}(\mathrm{~A})$ and $\mathrm{P}_{\text {peak }}=140 \mathrm{~Pa}(137 \mathrm{~dB}(\mathrm{C}) \mathrm{re}$. $20 \mu \mathrm{Pa})$,

c) lower exposure action values: 
$\mathrm{L}_{\mathrm{EX}, 8 \mathrm{~h}}=80 \mathrm{~dB}(\mathrm{~A})$ and $\mathrm{P}_{\text {peak }}=112 \mathrm{~Pa}(135 \mathrm{~dB}(\mathrm{C})$ re. $20 \mu \mathrm{Pa}$ ).

where: $\mathrm{P}_{\text {peak }}$ - peak sound pressure ( $\mathrm{Pa}$, i.e. maximum sound pressure value measure with ' $\mathrm{C}$ ' frequency correction), $\mathrm{L}_{\mathrm{EX}, 8 \mathrm{~h}}$ - daily noise exposure level $(\mathrm{dB}(\mathrm{A})$ re. $20 \mu \mathrm{Pa})$, i.e. is the average $\mathrm{A}$ weighted noise exposure level for a nominal 8-hour working day, calculated in accordance to ISO 1999: 1990 p. 3.6 [2] and is applied to all types of noise present at work, including impulsive noise. These guidelines apply only to the working environment. World Health Organization (WHO) guidelines for community noise recommend less than $30 \mathrm{~dB}(\mathrm{~A})$ in bedrooms during the night for a good quality sleep and less than $35 \mathrm{~dB}(\mathrm{~A})$ in classrooms to allow good teaching and learning conditions. WHO guidelines for night noise recommend less than $40 \mathrm{~dB}(\mathrm{~A})$ of annual average ( $\left.\mathrm{L}_{\text {night }}\right)$ outside bedrooms to prevent adverse health effects from night noise [3].

Regular exposure to too high noise levels by human is the main reason for the growing number of people suffering from hearing loss. There is about 466 million people with significant hearing loss all over the world, including 34 million children (7\% of population). East-Central Europe and Central Asia contribute to nearly $7.5 \%$ of the overall prevalence. Among adults over the age of 65 , nearly 1 in 3 experience disabling hearing loss [4]. The majority of people with disabling hearing loss live in low- and middle-income countries. Moreover, WHO estimates that approximately $15 \%$ of the world's adult population experiences some degree of hearing loss and about 1.1 billion young people worldwide are at risk of hearing loss from unsafe listening practices. This includes exposure to loud sounds on personal audio devices and in noisy entertainment venues. WHO estimated that 630 million people will have hearing loss by 2030 and over 900 million in 2050 [5]. Hearing damage is the most common disturbance of humans' sensory organs. Estimates refer to $10 \%$ of the population, while the frequency of hearing loss increases with age and can affect up to $30 \%$ of people in the old age. Hearing damage related to occupational exposure to noise accounts for approximately $16 \%$ of hearing loss in the entire adult population.

A professional, diagnostic hearing test is timeconsuming, requires the presence of a specialist, professional equipment and an acoustically adapted room [6]. For this reason, many people are unable to check the state of their hearing. Based on the above information, authors decided that an interesting and useful solution would be to create an Android mobile application for hearing loss screening. It is obvious that this type of application cannot replace hearing tests carried out in a professional audiology laboratories. However, the application may provide a feedback to a person who suspects that he/she is hearing impaired, if he/she should consult a specialist or if his/her hearing is normal. The great advantage of mobile applications for Android is availability. Over 2.53 billion people all over the world use Android devices. The share of Android in the market of mobile operating systems is $85.9 \%$ [7]. This worldwide popularity means that the system is intensively developed and has a stable, well-documented and supported programming environment, as well as many tools, libraries and additions. Due to this fact, developers can effectively create any application. In addition, unlike computers, smartphones are small, handy devices that can be easily transported and used anywhere. With the help of a mobile hearing test application, the user can check his/her hearing in a quick and pleasant way.

Considering the above, the goal of this project was to develop a mobile application for hearing testing using pure-tone audiometry comparable to the tests carried out in accordance with the guidelines contained in ISO 8253-1:2010. The mobile application has been tested for the correctness of test results. The study group consisted of patients of all ages who underwent the study of tonal audiometry. The validation was done by comparing mobile application test results with professional clinical audiometer Interacoustics AD629.

\section{HEARING LOSS}

Hearing impairment may be defined as a reduction in hearing acuity or sensitivity, or presence of tinnitus. It relates primarily to the inability of the affected individual to hear sounds at certain levels. This is tested by presenting pure tones at frequencies of $125 \mathrm{~Hz}, 250 \mathrm{~Hz}, 500 \mathrm{~Hz}$, $1 \mathrm{kHz}, 2 \mathrm{kHz}, 4 \mathrm{kHz}, 6 \mathrm{kHz}$ and $8 \mathrm{kHz}$ and is shown with accuracy to within 5 or $3 \mathrm{dBHL}$ on a chart known as an audiogram. The threshold of hearing is defined as $0 \mathrm{dBHL}$.and it represents the reference level of normal hearing. It is generally accepted that hearing thresholds ranging from 0 to $20 \mathrm{dBHL}$ may be deemed within 'normal' limits. Thus any threshold levels at any of the audiometric frequencies listed above may constitute a hearing loss at that frequency of a given amount raised above normal.

Hearing impairment can be caused by diseases of the cord external auditory canal and middle ear (conductive hearing loss) or due to internal ear damage, auditory nerve (sensorineural hearing loss) or a central type hearing loss related to damage on the nervous path above the intersection of the auditory pathways. If the sensorineural hearing loss coexists with the conductive hearing loss, then a mixed hearing loss arises. Hearing impairment can be unilateral or bilateral; sharp or chronic. There may be all degrees of hearing impairment from light to total deafness. This issue is widely described in the literature among others $[8,9,10]$. 


\subsection{Audiometric Classification according to BIAP (International Bureau for Audiophonology) [12]}

After a clinical examination has been conducted, an audiometric measurement can be done in satisfactory acoustic conditions. It shows a loss in $\mathrm{dB}$, compared with normal hearing level (dBHL), with reference to ISO standards. An average tone loss is calculated, taking as a starting point the loss in $\mathrm{dB}$ at various frequencies: $500 \mathrm{~Hz}$, $1000 \mathrm{~Hz}, 2000 \mathrm{~Hz}$ and $4000 \mathrm{~Hz}$. A frequency which is not perceived is considered as a loss of $120 \mathrm{~dB}$. The total amount is calculated, divided by 4 and rounded up to the nearest value. In the event of an asymmetric hearing loss of more than $15 \mathrm{~dB}$, the average loss level, expressed in $\mathrm{dB}$, is multiplied by 7 for the 'good' ear and by 3 for the 'bad' ear. Then, the total is divided by 10 .

Classification of hearing loss (BIAP):

I. Normal or subnormal hearing

The average tone loss is below $20 \mathrm{~dB}$.

Mild tone disorder with no social consequences.

\section{Mild hearing loss}

Average tone loss between 21 and $40 \mathrm{~dB}$.

Speech is perceived if the voice is normal, difficulties arise if the voice is low-pitched or distant from the subject. Most of the daily life noises are perceived.

\section{Moderate hearing loss}

- 1st degree: average tone loss between 41 and 55 $\mathrm{dB}$.

- 2nd degree: average tone loss between 56 and 70 $\mathrm{dB}$.

Speech is perceived if the voice is loud. The subject understands better what is being said if he/she can see his/her interlocutor. Some daily life noises are still perceived.

\section{Severe hearing loss}

- 1st degree: average tone loss between 71 and 80 $\mathrm{dB}$.

- 2nd degree: average tone loss between 81 and 90 $\mathrm{dB}$.

Speech is perceived if the voice is loud and close to the ear.

Loud noises are perceived.

\section{Very severe hearing loss}

- 1st degree: average tone loss between 91 and 100 $\mathrm{dB}$.

- 2nd degree: average tone loss between 101 and $110 \mathrm{~dB}$.

- 3rd degree: average tone loss between 111 and $119 \mathrm{~dB}$.

Speech is not perceived.

Only very loud noises are perceived.

VI. Total hearing loss - Cophosis

Average tone loss over $120 \mathrm{~dB}$.

Nothing is perceived.

\subsection{Audiometric Classification according to World Health Organization [13]}

WHO classified hearing impairment according to the pure-tone average determined for the better hearing ear. Categories of hearing impairment range from 'no impairment' to 'profound impairment' in reference to the threshold level. The hearing threshold level, using audiometry, is to be taken as the better ear average for four frequencies $500 \mathrm{~Hz}, 1000 \mathrm{~Hz}, 2000 \mathrm{~Hz}$ and $4000 \mathrm{~Hz}$. The different grades of hearing impairment and their impact in performance are presented Table 1 .

Table 1. World Health Organization Grades of Hearing Impairement (WHO, 2008)

\begin{tabular}{|c|c|c|}
\hline $\begin{array}{c}\text { Grade of } \\
\text { impairment* }\end{array}$ & $\begin{array}{l}\text { Corresponding } \\
\text { audiometric } \\
\text { ISO value }{ }^{* *}\end{array}$ & Performance \\
\hline $\begin{array}{c}0 \text { - No } \\
\text { impairment }\end{array}$ & $\begin{array}{l}25 \mathrm{~dB} \text { or better } \\
\text { (better ear) }\end{array}$ & $\begin{array}{c}\text { No or very } \\
\text { slight hearing } \\
\text { problems. Able } \\
\text { to hear } \\
\text { whispers. } \\
\end{array}$ \\
\hline $\begin{array}{l}1 \text { - Slight } \\
\text { impairment }\end{array}$ & $\begin{array}{l}26-40 \mathrm{~dB} \\
\text { (better ear) }\end{array}$ & $\begin{array}{l}\text { Able to hear and } \\
\text { repeat words } \\
\text { spoken in } \\
\text { normal voice at } \\
1 \text { metre. }\end{array}$ \\
\hline $\begin{array}{l}2 \text { - Moderate } \\
\text { impairment }\end{array}$ & $\begin{array}{l}41-60 \mathrm{~dB} \\
\text { (better ear) }\end{array}$ & $\begin{array}{l}\text { Able to hear and } \\
\text { repeat words } \\
\text { spoken in raised } \\
\text { voice at } 1 \text { metre. }\end{array}$ \\
\hline $\begin{array}{l}3 \text { - Severe } \\
\text { impairment }\end{array}$ & $\begin{array}{l}61-80 \mathrm{~dB} \\
\text { (better ear) }\end{array}$ & $\begin{array}{l}\text { Able to hear } \\
\text { some words } \\
\text { when shouted } \\
\text { into better ear. }\end{array}$ \\
\hline $\begin{array}{c}4 \text { - Profound } \\
\text { impairment } \\
\text { including } \\
\text { deafness }\end{array}$ & $\begin{array}{l}81 \mathrm{~dB} \text { or greater } \\
\text { (better ear) }\end{array}$ & $\begin{array}{c}\text { Unable to hear } \\
\text { and understand } \\
\text { even a shouted } \\
\text { voice. }\end{array}$ \\
\hline
\end{tabular}

* Grades 2, 3 and 4 are classified as disabling hearing

impairment (for children, it starts at $31 \mathrm{~dB}$ )

** The audiometric ISO values are averages of values at 500 , 1000, 2000, $4000 \mathrm{~Hz}$.

The choice by BIAP and WHO of these four frequencies $(500 \mathrm{~Hz}, 1000 \mathrm{~Hz}, 2000 \mathrm{~Hz}$ and 4000 $\mathrm{Hz}$ ) was not accidental. These frequencies are crucial for humans, because of the communication and reception of human speech. The ability to communicate freely is one of fundamental human needs. Thus, the frequency band of the speech signal reception should be as good as possible.

When discussing hearing impairments, it is also worth to mention tinnitus. Tinnitus consists of the presence of an auditory sensation in one or two ears or in the head, without an external sound stimulus. Most often it occurs in the form of noise squeaking or ringing. This is a rather arduous condition that affects about $17 \%$ of people. Finding the cause of its origin is difficult - tinnitus most often arises as a result of damage to the cochlea, auditory path or higher floors of the auditory system. Tinnitus is not the subject of this project, as 
the audiometric tests cannot be used for its detection.

\section{PURE-TONE AIR AND BONE CONDUCTION AUDIOMETRY}

The basic tool used in threshold audiometry is the audiometer. It is a specialized device which main task is the generation of acoustic signals. Requirements for the construction of audiometers can be found in the international standard IEC 60645-1 [15]. Figure 1 presents a view of a clinical audiometer with additional equipment (headphones, patient response switch, bone vibrator, etc.) used in this project.

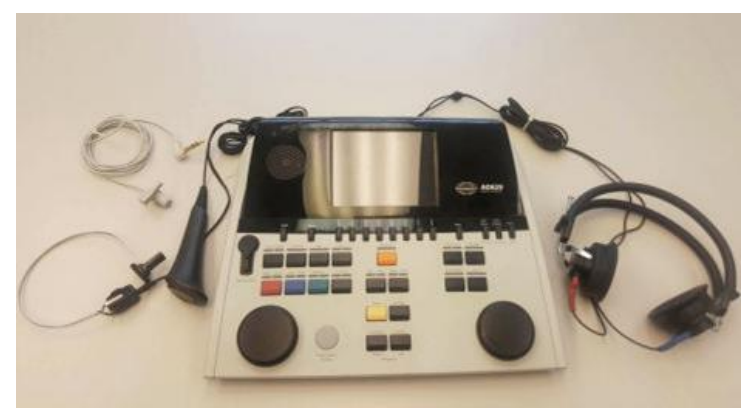

Fig. 1. Audiometer Interacoustics AD629 [14]

The results of audiometric tests are presented as audiograms. The audiogram is a graph showing the course of hearing threshold of the examined person. The horizontal axis represents the frequencies for which the test was carried out $(125 \mathrm{~Hz} \div 8 \mathrm{kHz})$, while the vertical axis is the audibility threshold given in logarithmic scale dBHL (dB hearing level). The audibility threshold, also referred to as the lower limit of hearing, is the limit of hearing, i.e. the minimum sound volume for which the patient feels the auditory sensation. The values of hearing thresholds for subsequent frequencies are combined with each other by means of a broken curve, called the hearing threshold. As the $0 \mathrm{dBHL}$ level, the average hearing threshold is assumed, for a specific frequency, measured for a normally hearing person (the calibration standard for audiometric devices to the level of $0 \mathrm{dBHL}$ is set by the international standard ISO 389-1:2017 [16]). Based on this information, it is easy to deduce that the audiogram represents the patient's hearing thresholds for given frequencies in relation to the hearing thresholds of people with normal hearing. This type of presentation of results is very well legible and allows assessment of hearing loss as well as initial diagnostics. On the audiogram (Figure 2), the left ear is marked in blue and the right one in red. Various types of markings are also used (Table 2), defined in ISO-8253, which symbolize the types of tests carried out.
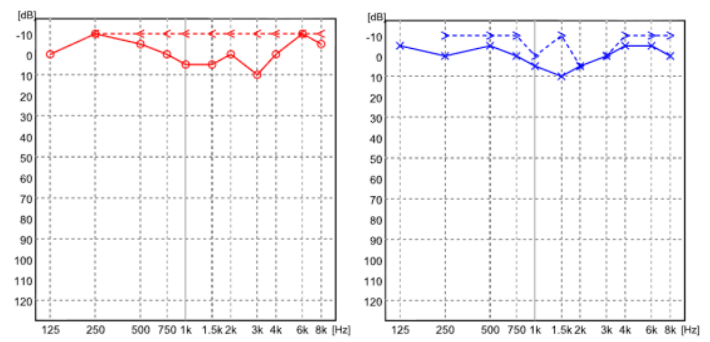

Fig. 2. Sample audiogram results of air (solid line) and bone (dotted line) conduction audiometry for normal hearing. Red lines - right ear, blue lines - left ear.

Table 2. Symbols and corresponding types of audiometric tests [7]

\begin{tabular}{|c|c|c|}
\hline Left ear & Right ear & types of audiometric tests [7] \\
\hline $\mathrm{x}$ & $\mathrm{o}$ & $\begin{array}{c}\text { Pure-tone of test } \\
\text { audiometry }\end{array}$ \\
\hline$\Gamma$ & 7 & $\begin{array}{c}\text { Pure-tone bone conduction } \\
\text { audiometry with masking signal }\end{array}$ \\
\hline$>$ & $<$ & $\begin{array}{c}\text { Pure-tone bone conduction } \\
\text { audiometry }\end{array}$ \\
\hline
\end{tabular}

An important term in the interpretation of the results of the hearing test based on the audiogram is the cochlear reserve, i.e. the space separating puretone audiometry curves - air and bone conduction. Based on the cochlear reserve, it is possible to determine the type of hearing loss:

- conductive hearing loss - there is a cochlear reserve; the curve of the hearing threshold for bone audiometry is normal, while the curve of the hearing threshold for the pure-tone air conduction audiometry lies between the level 0 $\mathrm{dBHL}$ and $60 \mathrm{dBHL}$,

- mixed hearing loss - there is a cochlear reserve; the curve of the hearing threshold of bone audiometry is below the level of $0 \mathrm{dBHL}$,

- receiving hearing loss - no cochlear reserve.

Pure-tone audiometry of air conduction is based on the presentation of a test signal to a patient using headphones, while in the case of bone conduction a bone vibrator is used for this purpose. The tests are performed separately for each ear. As the source signal, a single tone (pure-tone audiometry) or a variable frequency signal (e.g. Békésy audiometry) can be used.

\section{4. 'HEARING TESTER' MOBILE APPLICATION}

The development of a mobile application for the hearing loss screening using air conduction audiometry was carried out in accordance with the standards of the software engineering process [17]. The completed work can be divided into five main stages (the so-called Software Development Lifecycle): (i) Analysis of requirements (goal: to define the assumptions - the requirements and functionality of the application); (ii) Design (goal: to create a user interface project and initial design of a software architecture); (iii) Implementation (goal: implementing solutions and creating software 
that meets the assumptions); (iv) Testing (goal: to test the software for compliance with the design assumptions); and (v) Deployment (goal: providing and using the application for its intended purpose).

\subsection{Main assumption and objective of the 'Hearing Tester' application}

The application should answer the user with the following questions: Is my hearing normal? Are there any indications that I have a hearing loss and should consult a specialist?

Other assumptions:

1. The application is designed to enable users to carry out a preliminary hearing test at home in a quick and easy way.

2. Hearing test is to be performed by means of pure-tone air conduction audiometry.

3 . The course of the hearing test performed with the application is to be as close as possible to the procedures described in the ISO 8253-1: 2010 standard.

4. The application is to operate on mobile devices with Android system.

5. The application is to be user-friendly, intuitive to use, the application interface must be responsive.

Additional functionalities:

a. Results - the user must be able to see his/her results in the form of an audiogram.

b. Calibration - before the test, the device should be calibrated and the listening should be carried out. Calibration must be both accurate and quick to make.

c. Settings - possibility of configuring the test run e.g. changing the precision of a test.

d. Instruction - manual for the application along with a description of the procedure of the hearing test.

Figure 3 presents the main view and manual window of 'Hearing Tester' and Table 3 contains problems and solutions adopted at the application design stage.

\subsection{Calibration and settings}

A very important aspect that has a significant impact on the correctness of test results is the calibration of measurement chain - the mobile device and headphones. The main purpose of the calibration for 'Hearing Tester' mobile application is to determine what gain on the linear (0-1) scale of the tone with the given frequency corresponds to the standard hearing threshold of the person with normal hearing, i.e. the level of $0 \mathrm{dBHL}$.

Due to the diversity of the market of mobile devices and the headphones market, as well as the lack of exact specifications of digital-to-analogue converters used in mobile devices, traditional methods of calibration are difficult. In addition, mobile applications are commonly used at home, by people who do not have access to specialized equipment. Therefore, the authors made decision to apply a biological calibration in the application [18].
Table 3. Basic problems and adopted solutions at the application design stage.

\begin{tabular}{|l|l|}
\hline \multicolumn{1}{|c|}{ Area of the problem } & \multicolumn{1}{c|}{ Solution } \\
\hline Technology & Native technology \\
\hline Programming language & Java version 8 [19] \\
\hline $\begin{array}{l}\text { Programming } \\
\text { environment }\end{array}$ & Android Studio 3.1.2 [19] \\
\hline Architectural pattern & $\begin{array}{l}\text { Model-View-Controller } \\
\text { (MVC) [22] }\end{array}$ \\
\hline $\begin{array}{l}\text { Tone generation \& } \\
\text { playback }\end{array}$ & $\begin{array}{l}\text { AudioTrack class [19] - a } \\
\text { complex class for audio } \\
\text { management and playback }\end{array}$ \\
\hline Saving results & $\begin{array}{l}\text { A relational database } \\
\text { based on the SQLite [19] } \\
\text { database engine was } \\
\text { selected to store patient } \\
\text { results, using the OrmLite } \\
\text { [21] external library to } \\
\text { support the database }\end{array}$ \\
\hline Generating graphs & $\begin{array}{l}\text { ExternalMPAndroidChart } \\
\text { library [20] was selected } \\
\text { for charts generation }\end{array}$ \\
\hline Calibration method & $\begin{array}{l}\text { The biological calibration } \\
\text { was selected (more in 4.2 } \\
\text { section Calibration and } \\
\text { settings) }\end{array}$ \\
\hline
\end{tabular}
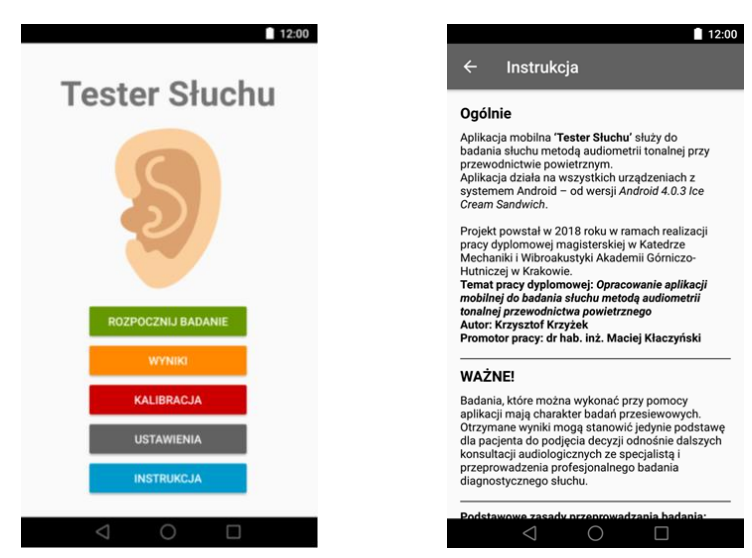

Fig. 3. a) main view b) manual window of 'Hearing Tester' mobile application

Performing the calibration is a necessary step before the hearing test. Calibration should be performed by a person with normal hearing, aged from 25 to 35 years [18]. Its task is to adjust the gain by means of the gain adjustment buttons and to set his/her hearing threshold for $1 \mathrm{kHz}$ frequency with an accuracy of $1.0 \mathrm{~dB}$. After determining the appropriate level and clicking the CALIBRATE button, the calibration coefficients are calculated for the remaining frequencies based on the correction curve A and formula 1 [23].

$$
\begin{aligned}
& W_{A}=10 \log \left[\frac{1.562339 f^{4}}{\left(f^{2}+107.65265^{2}\right)\left(f^{2}+737.86223^{2}\right)}\right] \\
& +10 \log \left[\frac{2.232881 \cdot 10^{16} f^{4}}{\left(f^{2}+20.598997^{2}\right)^{2}\left(f^{2}+12194.22^{2}\right)^{2}}\right]
\end{aligned}
$$

where:

$\mathrm{W}_{\mathrm{A}}=$ weighting to be applied $[\mathrm{dB}]$ 
$\mathrm{f}=$ frequency $[\mathrm{Hz}]$

Table 4. Calculated correction values for the frequencies used in the test.

\begin{tabular}{|c|c|}
\hline Frequency [Hz] & Correction factor [dB] \\
\hline 125 & -16.1 \\
\hline 250 & -8.6 \\
\hline 500 & -3.2 \\
\hline 1000 & 0.0 \\
\hline 2000 & 1.2 \\
\hline 4000 & 1.0 \\
\hline 8000 & -1.1 \\
\hline
\end{tabular}

In the 'Hearing Tester' mobile application, as the level of $0 \mathrm{dBHL}$ for the $1 \mathrm{kHz}$ tone, the gain determined manually by the person performing the calibration is taken. The gain values for remaining frequencies are corrected by the correction factors calculated on the basis of the curve A (Table 4) with the opposite sign and gain value determined for $0 \mathrm{dBHL}$. The calibration menu is shown at Figure $4 \mathrm{a}$.
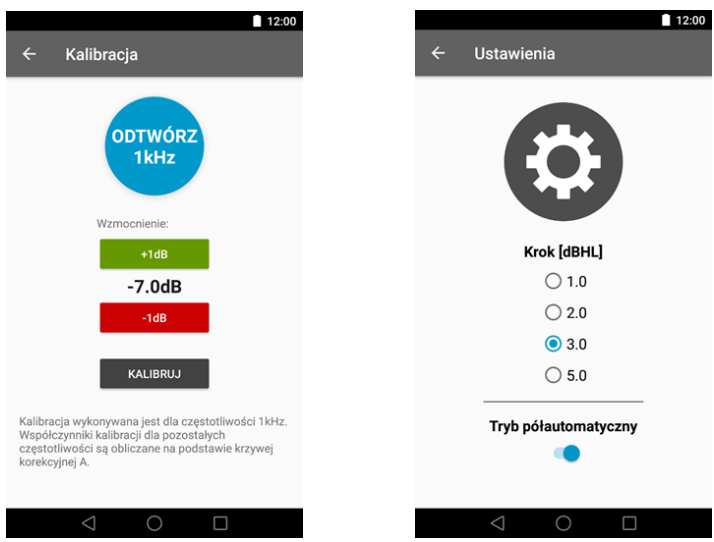

Fig. 4. a) calibration menu view b) settings view of 'Hearing Tester' mobile application

In the settings view, the user can modify two hearing test parameters: test precision and test mode (Figure 4b). Step selection buttons can be used for adjusting accuracy at which the patient's hearing threshold is tested. Possible values are 1.0, $2.0,3.0$ or 5.0 [dBHL].

Semi-automatic mode toggle button enables or disables the semi-automatic hearing test mode. Activating the semi-automatic mode relieves the person conducting the test from the necessity to change the frequency after each single measurement of the hearing threshold. The test in semi-automatic mode starts at $1 \mathrm{kHz}$. Then, after determining and saving the hearing threshold for 1 $\mathrm{kHz}$ frequency, the following frequencies are automatically selected: $2 \mathrm{kHz}, 4 \mathrm{kHz}, 8 \mathrm{kHz}, 125$ $\mathrm{Hz}, 250 \mathrm{~Hz}, 500 \mathrm{~Hz}$ and again $1 \mathrm{kHz}$. Moreover, the default dBHL level for each frequency is automatically set to a level $10 \mathrm{~dB}$ lower than the patient's hearing threshold tested at $1 \mathrm{kHz}$. The default settings are: step $-3 \mathrm{dBHL}$, semi-automatic mode - turned off.

\subsection{Hearing test}

Before starting the test, it is mandatory to enter:

- first name and last name of the examined person,

- gender of the subject - a woman or a man to choose,

- age of the examined person.

The entered data is validated - i.e. until user has entered all the required information about the patient, the hearing test cannot be started (Figure $5 a)$. The measurement screen view of 'Hearing Tester' is shown on Figure 5b. The patient's first name and last name are displayed in the top action bar. The main view of the hearing test consists of two, identical fragments - LEFT EAR and RIGHT EAR, which contain the following elements:

- PLAY TONE button - after clicking this button, a tone corresponding to the selected frequency and the given gain is played. Additionally, during the playback of the tone, a red rectangle appears on the device's screen, which signals to the person conducting the research the fact of producing the sound.

The tone is generated in the application using the AudioTrack class object. Pure tone duration is 2 seconds with $22050 \mathrm{~Hz}$ sampling frequency and 16bit resolution.

- FREQUENCIES radio buttons - Available frequencies are $125 \mathrm{~Hz}, 250 \mathrm{~Hz}, 500 \mathrm{~Hz}, 1 \mathrm{kHz}$, $2 \mathrm{kHz}, 4 \mathrm{kHz}$ and $8 \mathrm{kHz}$.

- GAIN CONTROL buttons - these are used to adjust the gain (increase or decrease) of the played tone. The minimum gain value is equal to $-15 \mathrm{dBHL}$. The precision of the conducted test can be modified in the application settings. The user has the ability to adjust gain using a logarithmic scale - dBHL, while the volume of a generated sound in the application code is set by calling the setStereoVolume method (with parameters float leftGain, float rightGain) on the AudioTrack class object. This method takes values from the 0-1 range as an argument. For this reason, it is required to calculate the gain values from the logarithmic scale to a linear scale, and vice versa. It is done in accordance with the formula 2 :

$$
L_{x}=10 \log \left(\frac{\text { gain }}{\text { ref }}\right)^{2}
$$

were:

$L_{x}$ - level of gain on a logarithmic scale [dB] gain - gain value on a linear scale (0-1) ref - reference value, determined based on the calibration factor; separately for each frequency (01)

- SAVE VALUE button - used to save a single hearing threshold value. The saving of the value is signalled by a toast message and the change of the frequency's text color to green. One may overwrite the values for a given frequency many times. 
- SAVE RESULTS AND FINISH TEST button is used to complete one ear test and save the results. After clicking and confirming, the SAVE VALUE button is deactivated and the test cannot be redone.

- SEMI-AUTOMATIC MODE text field switching on the semi-automatic mode is signalled with the red text SEMI-AUTOMATIC MODE in the test view.
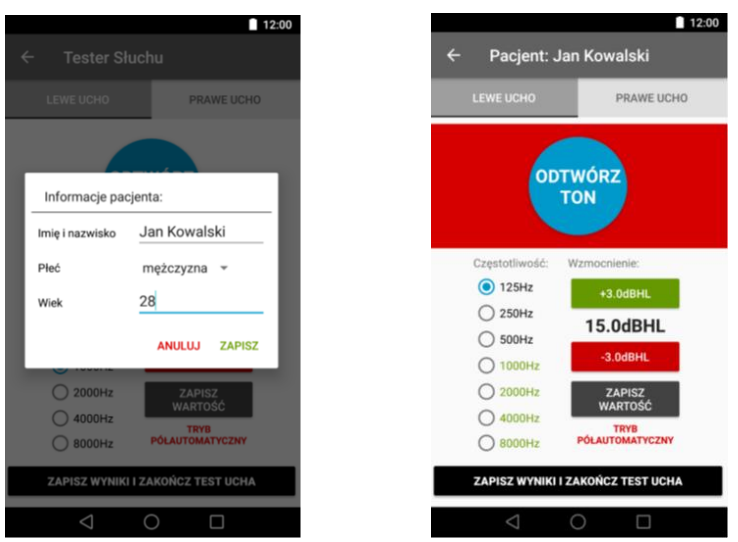

Fig.5. a) patient data view b) measurement screen view of 'Hearing Tester' mobile application

The test results are displayed in Results view. The audiograms are presented in a landscape orientation to better display the graph (Figure 6). In the audiogram, hearing threshold curves for the left (blue) and right (red) ear are marked, as well as:

- level $0 \mathrm{dBHL}$ - gray line,

- auditory range in the norm - green, dotted line; from $-15 \mathrm{dBHL}$ to $20 \mathrm{dBHL}$,

- range 'Consult with a specialist' - a red, dotted line; from $20 \mathrm{dBHL}$.

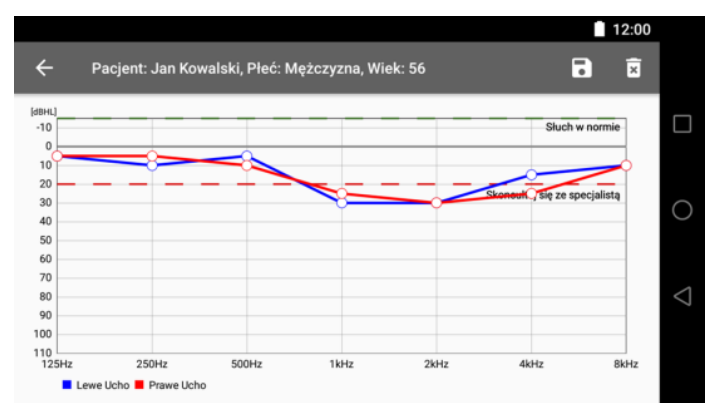

Fig. 6. Results view. Audiogram from 'Hearing Tester' mobile application

\section{COMPARATIVE HEARING TESTS}

The final part of the project was a comparative hearing test performed using the mobile application and the professional clinical audiometer Interacoustics AD629. The control group consisted of 6 people in different ages. The research was carried out in a small anechoic chamber of Department of Mechanics and Vibroacoustics at the AGH University of Science and technology in Krakow.
Hearing of patients was tested by a pure-tone air conduction audiometry, a signal of a rising level, in manual mode - in accordance with the procedure defined in ISO 8253-1: 2010 [7]. Each study consisted of five main phases:

1. Interview and conversation with the patient about the course of test.

2. Accustom the patient with the test procedure, for $1 \mathrm{kHz}$ frequency.

3. Proper hearing tests (by pure-tone air conduction audiometry, signal with increasing level).

4. Checking the patient's hearing threshold for 1 $\mathrm{kHz}$ frequency.

5. Repeat points 2-4 for the second ear.

6. Analysis and discussion on the results with the patient.

During the interview, the patients were asked to answer following questions:

- Do you have any hearing problems?

- On which ear do you hear with worse?

Each patient was examined using a mobile application and a clinical audiometer. The study time was from 30 to 50 minutes long, depending on the individual conditions. Table 5 presents a list of patients and information about them gathered during the interview phase.

\begin{tabular}{|l|l|l|l|}
\hline & Gender & Age & Preliminary interview \\
\hline 1 & F & 89 & Serious hearing problems \\
\hline 2 & M & 42 & Light hearing problems \\
\hline 3 & M & 86 & $\begin{array}{l}\text { Serious hearing problems. Left } \\
\text { ear worse }\end{array}$ \\
\hline 4 & M & 25 & No hearing problems \\
\hline 5 & F & 55 & Light hearing problems. Tinnitus \\
\hline 6 & M & 60 & Light hearing problems \\
\hline
\end{tabular}

Hearing tests using the application were carried out in an isolated, quiet room. The application was installed on a mobile device, namely a smartphone Huawei P8 (system version - Android 6.0 Marshmallow). Headphones recommended by the mobile device producer - AKG Y40 were used in the research. The selected equipment and the room in which the hearing test was performed were specifically chosen to simulate home conditions in which the application can be used by an ordinary user.

The results obtained during the hearing tests are presented on the audiograms (Figures $7 \div 10$ ). Separate charts for left and right ear are made for a patient 1 with serious problems and patient 4 with good hearing. On each audiogram, there are two hearing threshold curves - for a study performed using a clinical audiometer and for a test done using 'Hearing Tester' mobile application. The charts were constructed in a way to best present the comparison between the tests performed with the help of two different devices. 


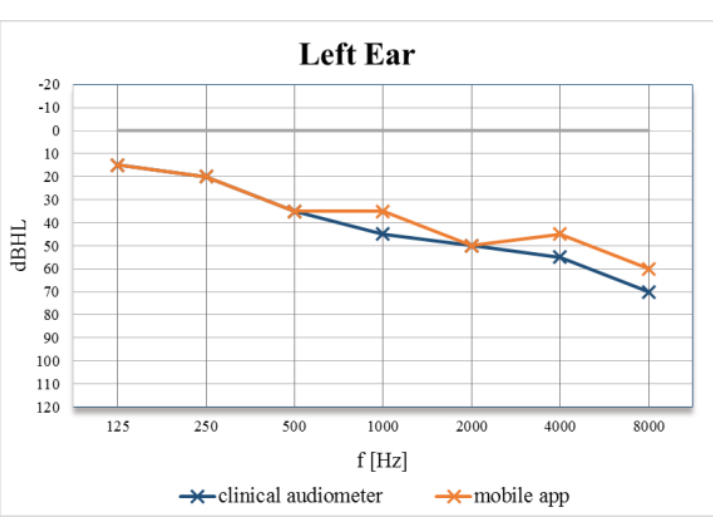

Fig. 7. Audiogram of a patient 1 , left ear

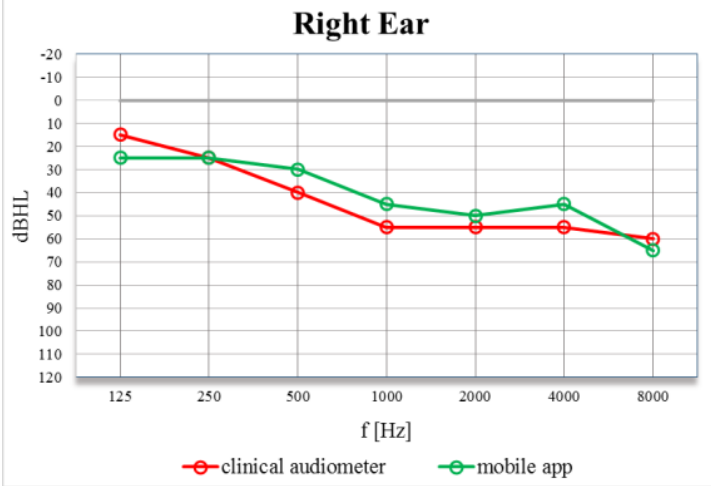

Fig.8. Audiogram of a patient 1, right ear

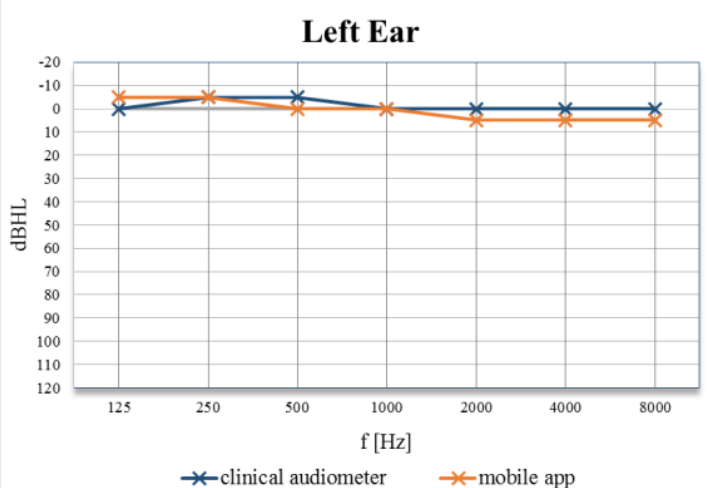

Fig. 9. Audiogram of a patient 4, left ear

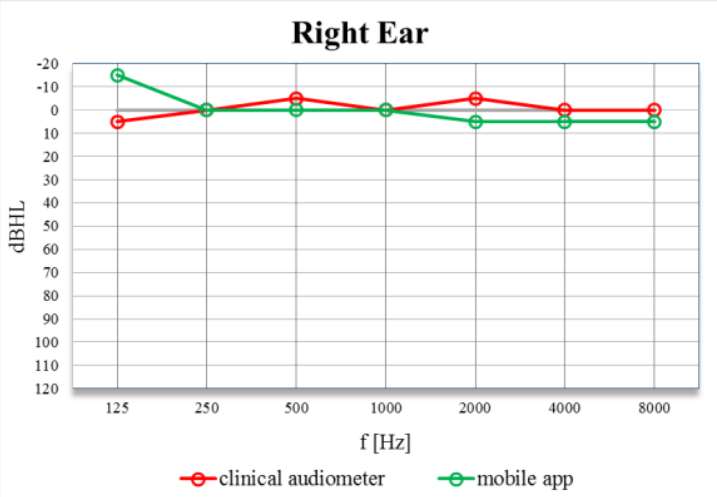

Fig. 10. Audiogram of a patient 4, right ear

Based on the interview and results of the research, general analysis of patients' hearing was made. The assessment was done in accordance with guidelines in line with the international BIAP standard [95]. Assessment examples:

Patient 1:

- light hearing loss for low frequencies,
- moderate hearing loss for medium and high frequencies,

- it is recommended to consult a specialist,

- the probable need for a hearing aid.

Patient 4:

- normal hearing for both ears, for all frequencies,

- no need to consult a specialist,

- no need to wear a hearing aid.

Obtained hearing test results using Interacoustics AD629 clinical audiometer are comparable to the results of hearing tests done with the usage of the implemented mobile application. The shapes of the hearing threshold curves are correctly preserved in the vast majority of cases. The average difference (for all patients) in the hearing threshold between the test results using the mobile application and the clinical audiometer test results was $5.2 \mathrm{dBHL}$, which is a very good result (the margin of error in the case of audiometric tests is $10 \mathrm{dBHL}$ [95]). In addition, the results coincide with information about the patients' hearing received from them during the interview.

Sources of errors in the results of tests performed using the mobile application may include:

- non-ideal conditions prevailing in the room, where the hearing test was carried out using the mobile application,

- calibration method of the mobile device and listening - inaccuracy of the biological calibration,

- hardware limitations - poor quality DAC converter in a mobile device and headphones,

- incorrect patient response to sound stimuli (especially in the case of older people).

\section{CONCLUSION}

The main goal of this project was to develop a mobile application for hearing loss screening using the method of pure-tone air conduction audiometry. The application was supposed to allow for the initial audiometric test according to the procedure defined in ISO 8253-1: 2010, based on which the user could get answers to following questions: Is my hearing correct? Should I consult a specialist?

'Hearing Tester' mobile application has been developed in a complex process consisting of five phases. The work on the application was carried out in accordance with the principles of software engineering and the software development lifecycle. The application is user-friendly, easy to use and allows you to perform a tone audiometry test with air conductivity in accordance with the international ISO standard. The final version of the application, in addition to the ability to perform hearing tests, allows for permanent saving of results in the form of audiograms, has the ability to modify the parameters of the study, and provides instructions and guidelines on how to perform puretone audiometry. The application development 
process ended with manual tests (interface tests, business logic and data storage).

Further development of the application is the most possible, among others: implement a different, more accurate calibration method; to automate the course of the hearing test; add new possibilities to modify the hearing test (i.e. more frequency of hearing threshold measurement, variable tone playback time); add the ability to export results to a .pdf file; migrate the application to other mobile platforms (i.e. iOS); create a global database of results and research statistics in the cloud.

The application is available for download and free use at https://play.google.com/store/apps 'Tester Słuchu'. Requirements: Android Mobile Device, Android min. ver. 4.0.3 Ice Cream Sandwich.

\section{ACKNOWLEDGEMENTS}

The work was created as part of the statutory research project of Department of Mechanics and Vibroacoustics AGH in Krakow (project No. 11.11.130.734).

\section{REFERENCES}

1. Directive 2003/10/EC of the European Parliament and of the Council of 6 February 2003 on the minimum health and safety requirements regarding the exposure of workers to the risks arising from physical agents (noise) (Seventeenth individual Directive within the meaning of Article 16(1) of Directive 89/391/EEC), Official Journal of the European Union, L 42/38, 2003

2. ISO 1999:1990 Acoustics - Determination of occupational noise exposure and estimation of noiseinduced hearing impairment (updated ISO 1999:2013)

3. Śliwińska-Kowalska M, Zaborowski K. WHO Environmental Noise Guidelines for the European Region: A Systematic Review on Environmental Noise and Permanent Hearing Loss and Tinnitus, Int. J. Environ. Res. Public Health 2017, 14(10): 1139. https://doi.org/10.3390/ijerph14101139

4. Website:http://www.euro.who.int/en/healthtopics/environment-and-health/noise/data-andstatistics (20190416)

5. Website:http://www.euro.who.int/en/countries/russia n-federation/news/news/2018/11/strengtheningcapacity-for-the-prevention-of-deafness-and-hearingloss (20190416)

6. Website: https://www.who.int/westernpacific/healthtopics/hearing-loss (20190416)

7. ISO 8253-1:2010 Acoustics - Audiometric test methods - Part 1: Pure-tone air and bone conduction audiometry

8. Statcounter - Global Stats. http://gs.statcounter.com/ (20160416)

9. Carrie L, Nieman, Nicholas S. Reed, Frank R. Lin, Otolaryngology for the Internist: Hearing Loss, Medical Clinics of North America, 2018;102(6):977992. https://doi.org/10.1016/j.mcna.2018.06.013
10. Jos J. Eggermon. Chapter 5 - Types of Hearing Loss, Hearing loss, Causes, Prevention and Treatment, 2017: 129-173

11. Luxon LM, Hearing Loss, Encyclopedia of the Neurological Sciences (Second Edition), 2014:533538.

12. BIAP Recommendation 02/1: Audiometric Classification of Hearing Impairments, October 26th, 1996 (http://www.biap.org, 20190416)

13. WHO: www.who.int/pbd/deafness/en/ (20190416)

14. Website: https://www.dotmed.com (20190417)

15. International Electrotechnical Commission IEC 60645-1:2017 Electroacoustics - Audiometric equipment - Part 1: Equipment for pure-tone and speech audiometry

16. ISO 389-1:2017 Acoustics - Reference zero for the calibration of audiometric equipment - Part 1: Reference equivalent threshold sound pressure levels for pure tones and supra-aural earphones

17. Phillips B, Stewart C, Marsicano K. Android Programming: The big nerd ranch guide. 3rd Edition, 2017.

18. Masalski M, Kręcicki T. Self-Test Web-Based PureTone Audiometry: Validity Evaluation and Measurement Error Analysis. Wrocław, 2013.

19. Website: https://developer.android.com/ (20190418)

20. Website:https://github.com/PhilJay/MPAndroidChart/ issues/164 (20190418)

21. Website: http://ormlite.com/ (20190418)

22. Buschmann F, Henney K, Douglas C. Schmidt: Pattern-oriented software architecture: On patterns and pattern languages. Wiley. 2007;(5):178-179.

23. Website:http://www.diracdelta.co.uk/science/source/a /w/aweighting/source.html\#.WvYXWaSFNaS (20190418)

Received 2019-03-10

Accepted 2019-06-13

Available online 2019-06-25

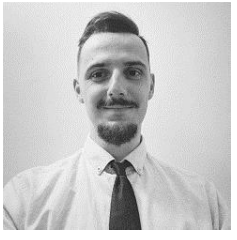

Krzysztof KRZYŻEK, M.Sc. Eng. in Acoustics Engineering, student of Application Programming and Design at the AGH University of Science and Technology. Digital Technology Leadership Program member at GE Healthcare, Android

Developer at Academic Computer Centre Cyfronet AGH, former Software Intern at IBM and Delphi. IT enthusiast passionate about software development, mobile solutions, emerging healthcare technologies and innovations.

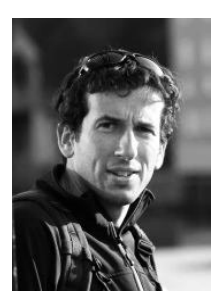

Maciej KŁACZYŃSKI Ph.D. D.Sc. Eng., works at Department of Mechanics and Vibroacoustics in AGH University of Science and Technology in Krakow. His research is focused on measurement, signal processing and pattern recognition methods of vibroacoustic signals applied in medicine, technology and environmental monitoring. Author of over one hundred scientific publications and conferences papers. Member of European Acoustics Association (EAA), Polish Acoustical Society (PTA) and Polish Society of Technical Diagnostics (PTDT). 